\title{
Comparative Study on the Distinctive Strategies and Factors of China's Negotiation with Taiwan and South Korea's Negotiation with North Korea: Focusing on the ECFA and GIC
}

\author{
Wonwoo Shin
}

\begin{abstract}
The purpose of this study is to compare the aspects of China's negotiation with Taiwan and South Korea's negotiation with North Korea around the Economic Cooperation Framework Agreement(ECFA) and Gaeseong Industrial Complex (GIC) negotiation cases, and to derive implications from the aspects of China's negotiation with Taiwan on the Inter-Korean relations, in a situation of a division. Conclusions drawn from this study are as follows. First, both China's negotiation with Taiwan and South Korea's negotiation with North Korea are emphasizing practical interests. Second, in terms of military security, South Korea should adjust its critical point in the engagement strategy toward North Korea to the level of China's critical point in the engagement strategy toward Taiwan. Third, South Korea should incorporate the organization responsible for Inter-Korean negotiations into the institutional system to hold the negotiation on a regular basis and also should seek for ways to grant the Inter-Korean agreement a legal status. Fourth, South Korea should minimize the changes in its North Korea policy arising from the change in the political camp and ruling party. Fifth, continuous efforts should be made to raise awareness among the South Korean people that the Inter-Korean economic cooperation project is not a means to provide a dispensational aid, but a part of investment to pursue mutual benefits. Lastly, the US influence on the Inter-Korean economic negotiations needs to be curtailed so that the negotiations are carried out in the framework of a bilateral negotiation.
\end{abstract}

Key Words: Cross-Strait Negotiations, Inter-Korean Negotiations, Economic Cooperation Framework Agreement(ECFA), Gaeseong Industrial Complex(GIC)

* Wonwoo Shin (hrhsw1107@gmail.com) is a Research Fellow in Institute of Chinese Studies at Hanyang University (Seoul Korea). He received his Ph.D. in International Studies from Hanyang University at Seoul. His fields of interest include Cross-Strait Relations, Inter-Korean Relations, and Negotiation Theory. This article is written partly based on the extracts from the Ph.D. dissertation of Wonwoo Shin 


\section{INTRODUCTION}

This article aims to derive implications on the management of intra-regional crisis resulting from a special situation, by comparing the characteristics of the Cross-Strait negotiations with Inter-Korean negotiations around the negotiation strategies and factors in special relations. It is worth comparing the Cross-Strait relation with Inter-Korean relation as they have similarities in that (1) they are based on the historical and cultural homogeneity of the same people, (2) they have experienced ideological conflict and regime competition over a long period, (3) they are significantly influenced by Internal and external factors. Above all, both sides of the Taiwan strait and both Koreas are aiming for co-existence and coprosperity through expansion of exchanges and cooperation and set reunification as a goal of their negotiations. Accordingly, despite their fundamental differences, the Cross-Strait relation and Inter-Korean relation are similar in that both are making efforts to develop their relations through dialogues and negotiations and as part of this effort they are utilizing non-political exchanges such as economic and private exchange (Moon 2007, 169). Therefore, the comparative study on Cross-Strait relations and Inter-Korean relations can significantly contribute to finding development in Inter-Korean exchange and cooperation in the future.

This article conducts a comparative analysis of the Cross-Strait and InterKorean negotiations around the factors impacting the negotiations, aiming to identify the causes of difference. In particular, while both relations share the common justifiable value of pursuing peaceful development in exchange and cooperation through negotiations, they show quite different aspects in the process, outcome and implementation of such negotiations to realize the value. Best example of this comparison is the negotiation for Economic Cooperation Framework Agreement (ECFA) between China and Taiwan and the Gaeseong Industrial Complex(GIC) negotiation between South and North Korea. ${ }^{1}$

The ECFA and GIC can be selected as an appropriate case for identifying the characteristics of the Cross-Strait negotiation and Inter-Korean negotiation because both ECFA and GIC negotiations have common characteristics as

\footnotetext{
${ }^{1}$ The ECFA and GIC project have been criticized as having fundamentally different scales of economic cooperation that cannot be compared to one another in a simple manner. However, the goal of this article is not simply comparing cases of economic cooperation but designing a model case of negotiation between nations that have special relations with each other (i.e., that share a homogenous ethnicity and experience of war yet have different political systems). Furthermore, given that both the cross-strait and Inter-Korean relations are based on national strategies of development through peaceful exchange and cooperation, the two negotiations are valuable cases in comparing the qualities of negotiations carried out by South Korea and China with the nations that have special relations with them, represented by cross-strait and Inter-Korean relations.
} 
follows. First, the Cross-Strait relation and Inter-Korean relation are special relations aiming for reunification. Second, the ECFA and GIC are good examples of symbolizing cooperative exchange. Of various means of reunification, the one through cooperative exchange development is a peaceful and the most effective way. Although the follow-up process for ECFA has been suspended since 2016 and GIC has also been tentatively closed since the same year, up until then both had been regarded as a successful case for cooperative exchange of the two nations. Lastly, the negotiation can be resumed anytime if the conditions are created. The Cross-Strait negotiation can be resumed if Taiwan acknowledges the '1992 Consensus.' In the case of Inter-Korean negotiation, although still closed, South and North Korea agreed on 19 September 2018 in the 'Pyeongyang joint declaration' to "Normalize the Gaeseong Industrial Complex and the Mt. Geumgang Tourism Project."

Of the negotiation theory studies, the study by Robert D. Putnam is a leading one. Here Putnam suggested the need to link International politics with domestic politics and introduced a 'Two-Level Theory' as a general theory to handle this in a comprehensive manner. As for the studies on the concept of negotiation, the concept introduced by Zartman is widely used. Zartman defined a negotiation as a "joint decision-making process among multiple actors." (Zartman 1983, 7-9) ${ }^{3}$ After the Cold War, Putnam's theory (1988) was magnified because the International negotiation issue was shifting from security to trade matters, for which the existing dichotomous study had limitations. More recently with globalization, negotiations have been taking place at various levels and as such, the importance of the factors impacting the negotiation is being highlighted. Also, the existing studies on negotiation generally covered how to gain the upper hand in negotiations, approaching from the perspective of conflict management, or how to derive consensus through study on case-by-case negotiations or

${ }^{2}$ Cheongwadae Briefings Speeches \& Remarks. 2018. "Pyeongyang Joint Declaration of September 20182 - (2)." Accessed at https://english1.president.go.kr/BriefingSpeeches/Briefings/322 (July 10, 2019).

3 The ECFA and GIC project have been criticized as having fundamentally different scales of economic cooperation that cannot be compared to one another in a simple manner. However, the goal of this article is not simply comparing cases of economic cooperation but designing a model case of negotiation between nations that have special relations with each other (i.e., that share a homogenous ethnicity and experience of war yet have different political systems). Furthermore, given that both the cross-strait and Inter-Korean relations are based on national strategies of development through peaceful exchange and cooperation, the two negotiations are valuable cases in comparing the qualities of negotiations carried out by South Korea and China with the nations that have special relations with them, represented by cross-strait and Inter-Korean relations. 
characteristics. ${ }^{4}$

This article analyzes the negotiation strategies and the factors impacting negotiation with a focus on the ECFA and GIC negotiations. First, as for studies on China's negotiation, there is a study by the Taiwanese scholar, Lin(2010, 2017), analyzed the characteristics of the cooperative exchange between China and Taiwan. and Shin(2010) studied its implications on Inter-Korean relations. Moon(2010) and Lee(2017) studied the characteristics of CrossStrait negotiation from institutional perspective. In general, most of the existing studies on the Cross-Strait negotiation or ECFA analyze the case itself, the negotiation result, or the (political and economic) impact on both nations after they reached agreement. However, there is not many attempting to analyze the negotiation strategy or the factors impacting the negotiation.

Since the end of the Cold War, the issues for International negotiations have gradually changed from security to trade. As the economic issues of the global society generally have direct impact on the concerned Interest groups or people, not only the analysis of the contents and process of the relevant policy negotiation but also the study on the factors influencing the negotiation started to be regarded important as well(Bergsten 1992, 3-24). Reflecting this trend, this study will perform the analysis of negotiations from two aspects: strategy and factor. Of these, the factors impacting negotiation are classified into (1) cultural - institutional factor, (2) political · economic factor, (3) external factor to identify the characteristics of the strategy and factors of China's negotiation with Taiwan and South Korea's negotiation with North Korea.

\section{THE ECFA NEGOTIATION AND GIC NEGOTIATION}

\section{CHINA'S ECFA NEGOTIATION WITH TAIWAN}

Since the 2000s Taiwan has not only suffered an isolation from the International community due to China's pressure, but also its domestic economic downturn has led to rise in the deficit of the national finance. As such, Taiwan's external/Internal political and economic conditions have been deteriorating. In particular, the global financial crisis in 2008 threw Taiwan's economy into a serious recession, and to overcome this economic downturn a public opinion

${ }^{4}$ There are studies on how to gain the upper hand in negotiations such as Bazerman and Neale (1994), Cohen (2001), Ury (2007). As for studies on ideological negotiation factor, the study by Young (1986). Young analyzed the negotiation behavior of a communist country. Young studied the Sino-US negotiations during the Cold War period between the two nations (1958 1967) from the aspect of ideology. 
among Taiwanese was formed that China should be seriously considered as a new market. Against this backdrop, Ma Yingjeou was elected President of Kuomintang(KMT), who emphasized political détente and expansion of economic cooperation with China as well as the cooperation with its major ally, the US. Also, Ma Yingjeou government maintained 'The New Three Noes' and announced that it would focus on economic exchanges based on the '1992 Consensus,' rather than on sensitive political discussions. Especially, the KMT under Ma Yingjeou regime suggested China should cooperate on the matters such as normalizing economic - cultural exchanges, avoiding the competition of attrition and entering into an International organization. The Beijing meeting in June 2008 defined a new Cross-Strait relation breaking from the conventional stance. As a result of this meeting, the 'Three Links policy' ${ }^{5}$ between the two sides was agreed, and consensus was reached on various areas including personnel . resource and economic exchanges. Business associations in Taiwan also started to demand for entering into the ECFA with China.

Taiwan considered the economic cooperation with China as an opportunity to avail itself of the huge market and capital of China and to make a breakthrough in its efforts to overcome the economic recession caused by the global financial crisis. Particularly, after Ma Yingjeou seized the power in 2009 Taiwan's economic growth rate recorded $-1.9 \%$. Hence, for Taiwan the efforts to reactivate its economy through economic cooperation with China became very critical. From China's perspective, the execution of the ECFA can be explained in two aspects, economic and political. In the economic aspect, China needed a cooperation for the advancement of its industrial structure, and Taiwan was considered as an appropriate partner. Up until then, the Chinese government had taken a very active stance on the FTA with South Korea, who on the other hand had shown a lukewarm attitude. In this situation, with Taiwanese government showing enthusiastic response to economic cooperation, China seems to have co-responded in the same manner to pursuing the economic cooperation with Taiwan. From political perspective, the ECFA negotiation means an economic integration having the purpose in political integration. Taiwanese President Ma Yingjeou also acknowledged that China harbored such political purpose when it made substantial concessions in the ECFA(Shin 2010, 90-91).

The ECFA consists of the Preface and 16 Articles under 5 Chapters. Although the ECFA provides for the terms of goods - services trade and investment Taiwan.

${ }^{5}$ Trade(通商), Transportation(especially airline, 通航), Postal(通邮) links between China and 
between China and Taiwan, in substance the Early Harvest Program(EHP) can be regarded as its core. ${ }^{6}$ With reference to the previous cases where it took a long time to agree on all the goods and services, the EHP allows early implementation of tariff cuts and market opening with regard to the specific goods designated, and through this builds up the institutional framework for economic cooperation. ${ }^{7}$ The ECFA is classified as a Basic Agreement. In International trade agreements, a Basic Agreement is usually composed of the agreement document and a concession specifying the "areas" for market opening. That is, a basic agreement, such as the ECFA, conventionally does not include the specific detailed "items" for market opening. Notwithstanding this, the annex of ECFA includes the EHP list between the two side of the strait. If we compare the economic effect of the EHP areas, it is more favorable to Taiwan than to China. This indicates that the EHP was realized as China had a political intention to achieve its political goal through economic concessions. In the course of negotiation, China expanded the scope of market opening toward Taiwan, which can be seen as a gesture to endorse the KMT in the 2012 Taiwanese general elections. In other words, it was intended to turn the table in favour of China in the long term by supporting the pro-China forces in Taiwan(Shin 2010, 88).

\section{SOUTH KOREA'S GIC NEGOTIATION WITH NORTH KOREA}

Discussions for the GIC began when the late Jeong Juyoung, the honorary chairman of Hyundai Group, suggested a plan during his two visits to North Korea in December 1998 and February 1999 to develop an industrial complex on the west coast covering a floor space of about $26,000,000\left(\mathrm{~m}^{2}\right)$ which was positively responded by North Korea(Heo 2011, 518). The GIC project was carried out as a means to concretely deliver the "June 15 Inter-Korean Joint Declaration," which was made possible by the engagement policy of the Kim Daejung government. The Inter-Korean 'Agreement on the development of Gaeseong Industrial District' in August 2000 and North Korea's designation of the Gaesong Industrial District in 2002 served as a momentum for a full-fledged operation of the project. As such, the project is meaningful in that it presented the one and only success model in the history of Inter-Korean economic cooperations. The GIC is also a good example of a Win-Win case in that both

\footnotetext{
${ }^{6}$ Matters other than the EHP, such as investment guarantee, intellectual property right protection, financial cooperation, customs, electronic commerce, industrial cooperation, and small $\cdot$ medium enterprise cooperation, were agreed only on a declarative level.

${ }^{7}$ The EHP reduces tariffs on 806 items for 2 years by three stages. Ultimate goal is to mutually implement a completely free trade through the gradual tariff cuts.
} 
Koreas would eventually gain from this mutually beneficial economic project. $^{8}$

The GIC project also bears political and social significance since it improves the Inter-Korean relations, promotes the reform and opening of North Korea, eases the military tension on the Korean Peninsular and improves North Korean people's perception on South Korea(Yang 2013, 57-58). However, in reality the engagement policy factor alone is not sufficient to explain the background for driving this project. Strictly speaking, the Inter-Korean economic cooperation involves not just the agreement by both Koreas, but is significantly influenced by the International community, especially the US factor. Basically, the InterKorean economic cooperation is operated on the virtuous cycle of three factors: South Korea's engagement policy approach to North Korea, North Korea's positive response, and International environment.

In short, the thawing mood toward North Korea in the International community around the US worked favorably for the Inter-Korean joint declaration on 15 June 2000, followed by actual implementation measures such as the GIC project, not ending as a mere declaration. In fact, due to the North Korean nuclear issues, the success of the GIC was not possible if there was no support, or at least tacit approval from the US.

The agenda of the GIC negotiation has two main features. First, while the agenda of general economic negotiations involve the tariff rate of goods and services, the agenda of the GIC mainly covers administrative operations such as salary, employment of workers, salary payment method, factory construction, land development and usage fee, electricity, communication, transportation and so forth. Second, detailed agreements on the main agenda of the GIC are only roughly described in the agreement, and specific matters can be identified through various laws and regulations as well as other agreements. Good examples are the 'Gaeseong Industrial Complex (GIC) Act' and 16 subregulations of North Korea and 'Gaeseong Industrial Zone Support Act' of South Korea. However, as the preemptive application of these laws is not easy in real situation, an Inter-Korean agreement is drafted for each main issue. As for the issues whose specific application is difficult even with such agreement, relevant

${ }^{8}$ The GIC project could provide economic and political benefits for both parties, if it is carried out as planned. To explain the project simply, it allows South Korea to utilize the labor and land of North Korea at a more economical rate than that of Vietnam, and North Korea will gain economic profit through the provisions. In addition, to a certain degree, the project can contribute to risk management on the Korean Peninsula. However, this particular article does not elaborate on the mutual benefits of the GIC. The reasons are as follows: first, in reality, the expected mutual benefits remain only "expected" benefits; second, this article does not focus on the success or failure, or benefits, of the GIC project, but on the characteristics of South Korea's negotiations with North Korea. 
regulations and detailed regulations are legislated.

\section{COMPARATIVE ANALYSIS ON THE STRATEGIES OF CHINA'S NEGOTIATION WITH TAIWAN AND SOUTH KOREA'S NEGOTIA- TION WITH NORTH KOREA}

This section compares the negotiation strategies of China and South Korea to identify the characteristics of the negotiation strategy under the situation of a national division as in China and South Korea, to explain the differences in their strategies, and finally to derive the characteristics of each negotiation strategy of China and South Korea. For this purpose, the strategy of Chinese negotiation with Taiwan for the ECFA will be compared with the South Korean strategy in its negotiation with North Korea for the GIC. China's strategy for its ECFA negotiations with Taiwan can be described with Entry Strategy, Engagement Strategy, Link Strategy and Influence Expansion Strategy. South Korea's strategy for its GIC negotiations with North Korea can be explained with Exit Strategy, Engagement Strategy, Link Strategy and Parallel Strategy.

Based on this analysis, the negotiation strategies of China and South Korea are compared using the figure below. Here, the negotiation strategy is approached by principle aspects, which can be generally extracted without considering specific areas, and it refers to an activity in which one analyzes the counter party's initial decision-making first and then seeks the ways to realize his/her own purpose to the maximum in the easiest manner.

Figure 1. Negotiation Strategy Types

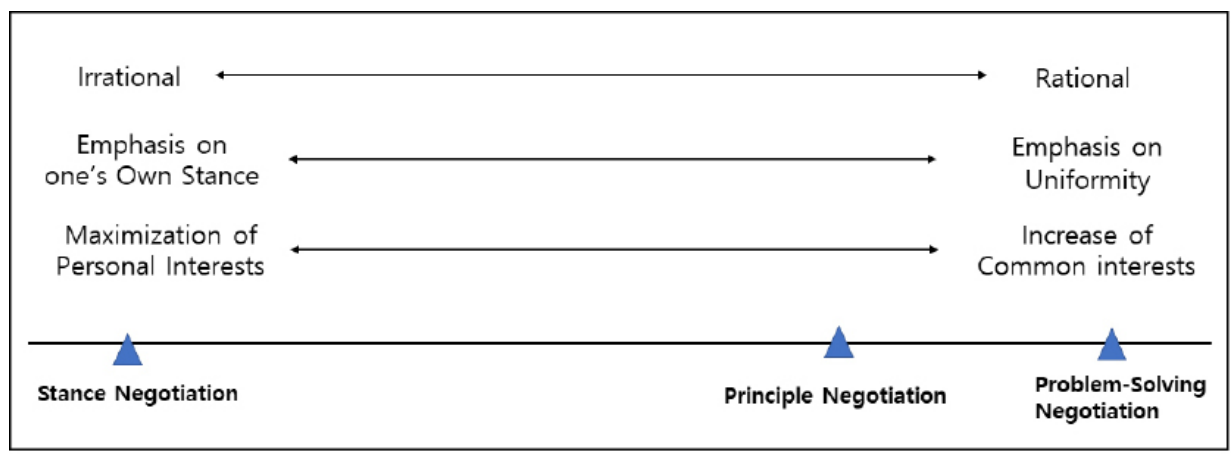

Source: Lee $(2005,160)$ 
Above line and the three triangles on it indicate the negotiation strategy types. Closer to the left, one understands the Inter-party relation as a strategic relationship of playing a zero-sum game while closer to the right side, one discloses most of information and seeks to address the common problem, i.e. mutual conflicts, in a cooperative manner. The triangle in the middle refers to a principle negotiation, having a nature of an alternative strategy to stance negotiation. While it is the same as the stance negotiation in that one considers the other party only strategically and does not disclose information, there is an emphasis on maintaining problem-solving approach, even if on normative basis. In this way, it can allegedly change the size of the combined Interests through the negotiation.

The stance and problem-solving negotiation in above picture are the extreme types hardly found in reality. Most of the negotiations fall under the principle negotiation type. However, they can be further classified by identifying around where it is located between the stance and problem-solving types. Above figure shows the three criteria used for classifying the strategy type, which are rational vs irrational, personal stance vs. community stance, and personal Interest vs. common Interest. Based on these criteria, the negotiation strategies of China and South Korea can be compared as follows.

Table 1. Chinese negotiation strategy with Taiwan vs. South Korean strategy with North Korea

\begin{tabular}{|c|c|c|c|}
\hline \multicolumn{2}{|r|}{ China } & \multicolumn{2}{|r|}{ South Korea } \\
\hline Strategy Type & Description & Strategy Type & Description \\
\hline Candidates & - Accept the 1992 Consensus & Exit strategy & $\begin{array}{l}\text { - Discuss easy problems first } \\
\text { - Pursue development in relations } \\
\text { through continued contacts }\end{array}$ \\
\hline $\begin{array}{l}\text { Engagement } \\
\text { strategy }\end{array}$ & $\begin{array}{l}\text { - Make up economic loss with } \\
\text { political surplus } \\
\text { - Secure historical legitimacy }\end{array}$ & $\begin{array}{l}\text { Engagement } \\
\text { strategy }\end{array}$ & $\begin{array}{l}\text { - Concede on economic agenda } \\
\text { - Minimize the impact of security } \\
\text { situation on economic cooperation }\end{array}$ \\
\hline Link strategy & $\begin{array}{l}\text { - Enhance Taiwan's economic } \\
\text { dependence on China } \\
\text { - Pursue natural reunification }\end{array}$ & Link strategy & $\begin{array}{l}\text { - Link political/military issues with } \\
\text { economic issues }\end{array}$ \\
\hline
\end{tabular}




\begin{tabular}{|c|c|c|c|}
\hline \multicolumn{2}{|r|}{ China } & \multicolumn{2}{|r|}{ South Korea } \\
\hline Strategy Type & Description & Strategy Type & Description \\
\hline $\begin{array}{c}\text { Influence } \\
\text { expansion } \\
\text { strategy }\end{array}$ & $\begin{array}{l}\text { - Proactively pursue FTA with } \\
\text { neighboring nations } \rightarrow \text { aim to } \\
\text { isolate Taiwan in International } \\
\text { community } \\
\text { - Expand pro-China sentiment } \\
\text { among Taiwanese } \\
\text { - Expand China-friendly businesses } \\
\text { in Taiwan } \\
\text { - Continued exchange with the } \\
\text { KMT(KMT-CPC Forum, etc.) } \\
\text { - Press releases and actively } \\
\text { publicize China's tolerant stance } \\
\text { toward the ECFA }\end{array}$ & $\begin{array}{l}\text { Parallel } \\
\text { strategy }\end{array}$ & $\begin{array}{l}\text { - Address economic cooperation } \\
\text { and nuclear issue at the same time } \\
\text { - Pursue political agenda and } \\
\text { economic agenda simultaneously }\end{array}$ \\
\hline
\end{tabular}

Source: Shin $(2019,145)$

\section{ENTRY STRATEGY VS. EXIT STRATEGY}

Both China's entry strategy and South Korea's exit strategy are related to each nation's stance on reunification. First, China's entry strategy is characterized by the fact that it has a precondition of agreement on the ' 1992 Consensus.' In other words, the agreement on the ' 1992 Consensus' is the entry to the negotiation. China has announced that its stance on the ' 1992 Consensus' is firm and NonNegotiable. Even starting the main ECFA negotiation, China reconfirmed this stance. During the 1st ECFA experts working-level negotiation held in Beijing on 16 January, both sides of the strait announced that they "intend to execute the ECFA at the earliest time possible in accordance with the following 4 principles: Address easy problems first, difficult problems later(先易後難); Pursue the same, change the difference(求同化异); Gradually move forward according to the order(循序漸進); Continue moving without stopping(积极稳妥).” ${ }^{9}$ China is strongly imprinting to the International community that the Cross-Strait issue is an Internal issue of China, expressing that it is even willing to use the military force in order to safeguard this. This can be based on the Chinese government's strategic judgement to set the Cross-Strait negotiation within the framework of a bilateral negotiation by preemptively blocking any Interruption

9 中華人民共和國中央人民政府. 2010. “海峡两岸经济合作框架协议首次专家工作商谈举行” (January 26). Accessed at http://www.gov.cn/jrzg/2010-01/26/content_151996o.htm (July 10, 2019). 
from foreign powers. On the issue of reunification as well, China takes the entry strategy maintaining that the premise for starting negotiation through dialogue is the agreement on the perspective on reunification. In fact, the progress in its negotiations with Taiwan also depends on this. ${ }^{10}$ The unfolding of the ECFA negotiation as analyzed in the previous section started from the agreement on the '1992 Consensus,' and since 2016 when a different Interpretation on this agreement was put out, the follow-up negotiation has been suspended. This Chinese strategy can be perceived irrational as you force the counterparty to accept your own stance, and if the counterparty does not fully accept your opinion, you change your attitude anytime. Also, by setting up the precondition of the ' 1992 Consensus,' China wants to have the effect of maximizing the strategic benefits of 'One China.' Therefore, the entry strategy of China can be close to the stance negotiation type.

On the other hand, South Korea is using the exit strategy in which reunification is set as the final objective. Agreement on the general principle with regard to the establishment of Inter-Korean relations and the methodology of reunification is clearly stated in the Inter-Korean Basic Agreement, which is still in effect. However, the problem is that its implementation is repeatedly suspended. Inter-Korean negotiations to tackle urgent issues such as the concern of the potential Inter-Korean military conflict and North Korean nuclear issues have been carried out regardless of the implementation or suspension of the agreement on the general principle regarding the establishment of Inter-Korean relations and the methodology of reunification. In other words, unlike the Cross-Strait negotiations, the Inter-Korean negotiations do not have a precondition of consistent agreement on reunification issue. Hence, the agreement on reunification issue is not the absolute factor in deciding whether to operate the Inter-Korean negotiations or not. In the GIC negotiation as well, the reunification issue was not mentioned unlike the Cross-Strait negotiations. This is possible because South and North Korea are using the exit strategy.

Accordingly, South Korea puts the principle agreements on reunification method or establishment of mutual relations, etc. on the back burner, and

10 According to the report of “Wang-Bao(旺报)” as quoted by a Chinese news agency on 16 May 2016, Sun Ya-fu(孫亞夫), the Vice President of the Association for Relations Across the Taiwan Straits(ARATS) clearly mentioned in the "One belt, One road" meeting with Taiwanese business leaders on 14 May as follows: "Unless the future Cross-Strait relation is based on the 1992 Consensus, there will be no new developments in institutionalizing the Cross-Strait economic cooperation, nor the ECFA follow-up agreement can be continued, and Taiwan's participation in the regional economic cooperation will also be affected." Sun said straightforwardly that the Cross-Strait cooperation and realization of national reunification are on the same line. : 大公网. 2016. “海协会官员: 无“九二共 识, ECFA难再续谈.”(May 16) Accessed at www.sohu.com/a/75731562_162548 (July 10, 2019). 
focuses its effort to address the easily solvable problems first. From the standpoint of the reciprocity principle, this can be called rational negotiation strategy in that (1) both parties recognize the other party as an equal principal in decision making, (2) by tackling the imminent issues first, mutual benefits are pursued and increase in common good is sought for, and (3) one party does not unilaterally ask for its demand. Thus, it can be said that South Korea's exit strategy is close to problem-solving negotiation.

\section{ENGAGEMENT STRATEGY}

China uses an engagement strategy toward Taiwan, and so does South Korea toward North Korea. China's engagement policy can be characterized by the strategy that, as long as Taiwan accepts the 1992 Consensus suggested by China, China will concede a substantial part of economic negotiations (Lin 2017, 122). China has always emphasized in its economic negotiations with Taiwan, such as ECFA, that the ECFA negotiations operate as an institutional device to realize the benefits of both parties to the maximum, not to economically subordinate Taiwan to China. ${ }^{11}$ Also it stresses that China should embrace Taiwan by conceding on economic agenda because it is a consideration for the same people based on a broad viewpoint, and desires to enhance its negotiation power by securing the cause and legitimacy as well as China-friendly forces within Taiwan. As such, China seeks to carry out the negotiations based on rational judgement. Thus, China's engagement policy can be called a principle negotiation close to problem-solving negotiation.

South Korea is also using the engagement strategy toward North Korea. As shown by South Korea's attitude during the 2008 and 2013 crisis of potential suspension of the GIC operation, South Korea has pursued to solve problems through dialogue even in crisis situations, recognized North Korea as an equal counterparty in the process of negotiation and tried to be considerate of North Korea on economic fields, maintaining its tolerant approach. Also, not unilaterally forcing its opinion, South Korea makes efforts to address problems through negotiations. Thus, the engagement strategy of South Korea can be also regarded as a principle negotiation close to problem-solving negotiation.

\footnotetext{
${ }^{11}$ The remark of ARATS Vice President, Cheong Rijung(鄭立中) can be an example. Cheong said at the 1st ECFA experts working-level negotiation held in Beijing on 26 Jan 2010, "the execution of the ECFA depends on the joint efforts of the people on both sides of the strait, and we will fully consider the hope and demand of Taiwanese compatriots. (We will) take fair and rational measures, respect the principle of equal and mutual benefit, and will carry out the ECFA negotiation proactively.” ; 中国新闻网. 2009. “郑立中表示两岸协商 ECFA 会考虑台湾市场承受能力.” (December 22). Accessed at http://www.arats.com.cn/duihua/200912/t20091230_1205788.htm (July 10, 2019).
} 
However, even though both are the same engagement strategy, their left-right positions on the strategy type line are not the same. South Korea's engagement strategy is characterized by the fact that it is still maintained even under the situation of North Korea's local provocation. This can be confirmed by the case of the GIC, which had continued operating until 2016 even under the situation of North Korea's military provocation. In the case of China, its engagement strategy toward Taiwan clearly does not tolerate such situation as Taiwan's military provocation.

To sum up, both nations' negotiation strategies have a tendency to make a concession on economic agenda. However, sanctions and pressure strategy are used under hostile situation, and if necessary, military threat is strategically used as well. South Korea's engagement strategy is soft compared to that of China, whose engagement strategy is hard relative to South Korea.

\section{LINK STRATEGY}

The link strategy is a strategy that intends to address a specific issue by linking the issue with a solution of a disparate agenda. Both China and Korea are using this link strategy in their negotiations with Taiwan and North Korea respectively. China desires to achieve its political purpose through an economic integration with Taiwan(Lin 2017, 203). The ECFA negotiation was also carried out in line with this context. In the $4^{\text {th }}$ Jinjiang meeting held on 22 December Chen Yunlin said, "The ECFA is simply an economic issue, and sensitive political issues will not be linked to this." This remark was intended to dispel the concern raised by some circles in Taiwan by separating the ECFA from political issues and to proceed the negotiation in favor of Taiwan. However, China's economic cooperation with Taiwan can be seen as a means to achieve its political objective of suppressing Taiwan's independence by expanding Taiwan's economic dependence on China through economic cooperation, and eventually realizing reunification in the natural course of events. Thus, in substance, China is carrying out the link strategy, attempting to achieve political integration through economic integration. To achieve this twofold objective, China's economic negotiations with Taiwan takes on the principle negotiation type close to problem-solving negotiation, just like the engagement strategy.

In South Korea as well, there are strategies that link different negotiation agenda such as economic negotiation and political negotiation. South Korea also can be seen using the link strategy in that it drives the Inter-Korean economic cooperation in order to pursue reunification through gradual development in their relations. However, South Korea's link strategy assumes different features depending on the government. In general, a conservative government tends to 
use the link strategy (Kim 2018, 200-201). In particular, when security issues occur such as nuclear issue and military conflict, the link strategy is used. In 2016 North Korea launched Kwangmyeongseong-ho satellite. To this, the South Korean government responded by announcing that it would not just sit and watch the military provocations mobilizing nuclear weapons and missiles and would suspend the entire GIC project. Also, following the 2010 'Cheonanham Incident', then President Lee Myungbak imposed sanctions against North Korea through the 'May 24 Measures', including forbidding of visits to North Korea - except to Mt. Keumgang and the GIC - and suspension of Inter-Korean exchange cooperation. Although in 2016 a tough measure, i.e. suspension of the GIC operation, was taken, up until then South Korea's stance had been to pursue a link strategy while keeping the door to dialogue open at the same time. Given this, South Korea's link strategy is also a principle negotiation type close to problem-solving negotiation.

\section{PATALLEL STRAGEGY}

The parallel strategy involves a simultaneous working of political agenda and economic agenda. South Korea employes a parallel strategy, which tackles the nuclear issue on one side while the exchange cooperation work is done on the other side in parallel. In the case of South Korea, this strategy has been used under progressive governments. The parallel strategy can be described as the negotiation methodology for the "exit strategy" of the Kim Daejung and Roh Moohyeon government. Especially the Roh Moohyun government decided to use the parallel principle for addressing Inter-Korean relations and nuclear issues and tried to put this into practice in reality (K. Park and J. Park 2008, 13). This strategy works as the most practical and effective strategy on a negotiation table where mutual distrust is overflowing. The usefulness of this strategy was proven in the process of negotiations for the 'September 19 Joint Statement' in 2005, 'June 15th Inter-Korean Joint Declaration' in 2000, and 'October $4^{\text {th }}$ InterKorean Summit Declaration’ in 2007.

This negotiation strategy of the South Korean government can also be found in the GIC negotiation process. Under the Kim Daejung and Roh Moohyeon governments, despite the outbreak of Yeonpyeong Island Battle or nuclear test, the GIC negotiations continued during the same period and negotiations on security issues were also carried out simultaneously. Given that this strategy is a cooperative negotiation strategy to avoid sensitive agenda and address imminent problems, a parallel strategy can also be regarded as a principle negotiation close to the problem-solving type. South Korea is strategically pursuing the parallel strategy to address two separate agendas of different nature, and because this 
strategy is voluntarily implemented, it is close to the problem-solving type principle negotiation.

\section{INFLUENCE EXPATION STRATEGY}

The influence expansion strategy refers to a strategy of pressing the counterparty to come to a negotiation table by surrounding the counterparty with available resources. The ECFA negotiation case shows that China's influence expansion strategy has been pushed ahead on various levels such as International relations, securing political/economic forces in Taiwan, and securing a favorable public opinion in Taiwan. The influence expansion strategy is the archetype of principle negotiation. The key to the principle negotiation is that problem-solving type approach can change the size of the combined benefits, and ultimately both parties can enjoy a larger pie. As shown in the ECFA negotiation case, in order to maximize its stance and Interests, China has successfully pressed Taiwan to come to the negotiation table by pursuing the FTA with the nations neighboring Taiwan, or blocking Taiwan's entry into the International community, and employing the strategy of securing pro-China circles within Taiwan.

And then, in the main negotiation, China generously made a substantial concession to Taiwan on economic agenda, giving more economic benefits to the counterparty. Based on this negotiation strategy of China, it can be said that influence expansion strategy has the typical features of the principle negotiation.

In South Korea, the case of using a meaningful influence expansion strategy can be hardly found in the GIC negotiations. However, at other times, South Korea pursues the influence expansion strategy, such as when there is an outbreak of military provocation by North Korea. For instance, when provocations by North Korea like the bombardment of Yeonpyeong Island or Cheonanham incident occur, instead of taking a tit-for-tat action, South Korea employes a strategy of pressing North Korea through collaboration with the International community such as the UN, or China and the US. This is intended to isolate North Korea by enhancing the exchange with China in a long term and to induce North Korea to come to the negotiation table. If North Korea responds to this, an engagement strategy is employed toward North Korea and common Interests are sought. In this aspect, South Korea's influence expansion strategy also assumes the characteristics of the principle negotiation. ${ }^{12}$

${ }^{12}$ This article does not elaborate upon the strategies of various security issues. However, a simple explanation on the effects of expansionist strategies of China and South Korea regarding security issues is required here. China has maintained a lukewarm attitude based on a basic principle for 
Figure 2. Comparison of the types of China's negotiation with Taiwan and South Korea's negotiation with North Korea

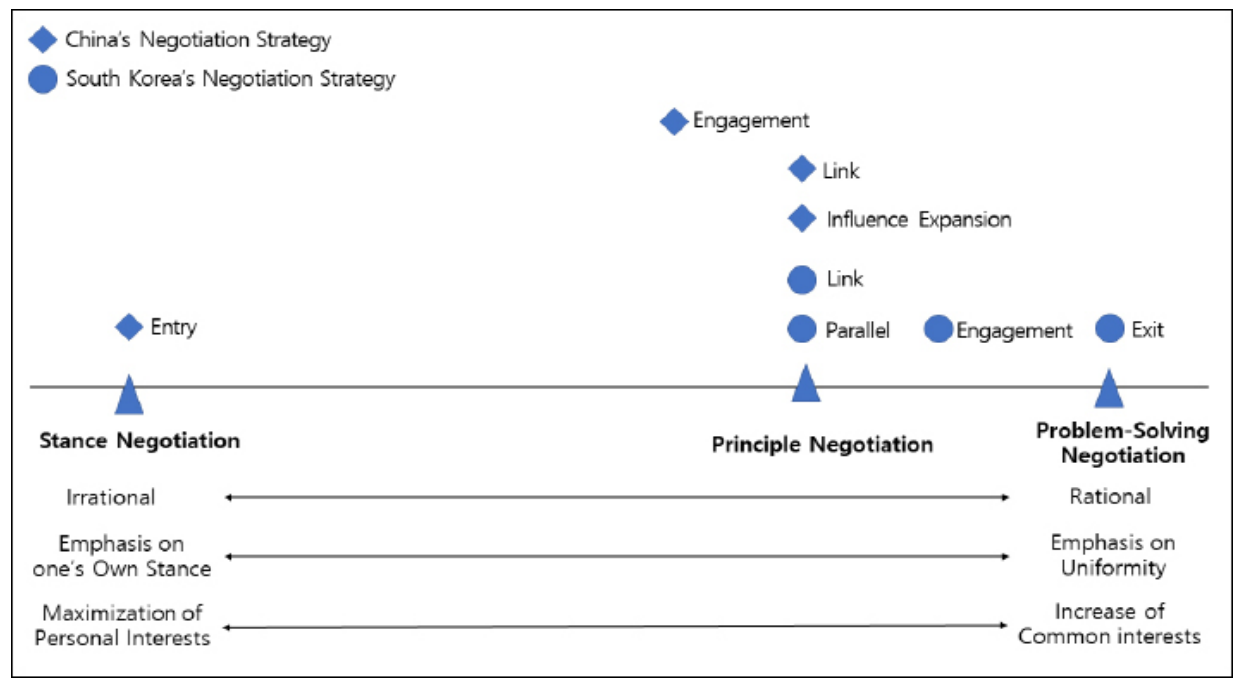

Source: Developed by the author based on Figure 1.; Shin $(2019,150)$

Above figure displays the negotiation types of South Korea and China analyzed in this section in a diagram. Based on above figure, the negotiation type of China against Taiwan and that of South Korea against North Korea can be described as follows: Stance negotiation type is used in China's entry strategy.

Problem-solving type negotiation is used in South Korea's exit strategy. Except for China's entry strategy and South Korea's exit strategy, all the strategies including engagement strategy, link strategy, influence expansion strategy and parallel strategy tend to be a principle negotiation close to a problem-solving negotiation. Provided, however, only the positions on the same line changes a little left or right. That is, South Korea's engagement strategy is located more closer to the problem-solving strategy than China's engagement strategy is. Differences between the engagement strategies of China and South Korea can be found in terms of the tolerance level China and South Korea show toward

not only the Cheonanham Incident, but also the nuclear weapons program and other security issues related to North Korea. Since it was hard to find cases on the influence expansion strategy among the characteristics of South Korea's Inter-Korean economic cooperation projects, this article briefly mentioned the Cheonanham Incident, a case in which the influence expansion strategy was used in the security sector. On the other hand, the author considers the lukewarm attitude of China as the evidence of a silent support for North Korea, as a part of the strategy to maintain its regional influence. 
Taiwan and North Korea respectively. In case of China, its scope of tolerance toward Taiwan does not include Taiwan's military provocation situations. On the contrary, unlike China, South Korea's engagement strategy has no such threshold line. In general, South Korea's engagement strategy shows the tendency of not linking military provocation situations including local provocation, with other disparate agenda. This can be verified by the case where the GIC had continued its operation up until 2016 even under the situation of North Korea's military provocation. Lastly, in case of China's entry strategy, which takes on a hard stance, if the counterparty accepts the 1992 Consensus, the threshold set by China, China's entry strategy will be immediately changed to the exit strategy, the same as used by South Korea.

Based on this result of strategy comparison between China's negotiation with Taiwan and South Korea's negotiation with North Korea, this article would like to opine as follows. First, China and South Korea have very similar negotiation strategy types. The only differences between these two is their strategy related to reunification: entry strategy vs. exit strategy. However, China's entry strategy, which takes on stance negotiation type, can also be converted anytime to a problem-solving negotiation type depending on the acceptance of the 1992 Consensus. Second, given the similarity in negotiation strategies, it is safe to say that the impact of negotiation strategy having on the different outcome of performance between the Cross-Strait and Inter-Korean negotiations are limited.

\section{COMPARISON OF THE FACTORS IN CHINA'S NEGOTIATION WITH TAIWAN AND SOUTH KOREA'S NEGOTIATION WITH NORTH KOREA}

This Section attempts to compare the Internal factors in China's negotiation with Taiwan and South Korea's negotiation with North Korea, by categorizing them into structural factors, political factors and economic factors. Structural factors include cultural, ideological and institutional factors. As for political factors, in case of China, Interpretation of the 1992 Consensus, China's Internal issues and Taiwan's political/social factors are reviewed. In case of South Korea, domestic political issues and political leader's characteristics ${ }^{13}$ are used for

${ }^{13}$ Belief or cognition of leaders are key determinants of international politics. Recently, scientization of psychological and cognitive assessment of political leaders have become a research trend (e.g. Fusion research using neuroscientific methods, analysis using operational code or Profiler 
political factor comparison. As for economic factors, Taiwan's economic factor in case of China and domestic economy issues in case of South Korea are compared to draw implications therefrom.

\section{COMPARISON OF CULTURAL AND INSTITUTIONAL FACTORS}

The cultural, ideological and institutional factors analyzed in this article do not have an absolute impact on negotiations. The culture, ideology and institution exist as general factors that underlie the negotiation actors. Thus, it is not easy to identify the specific cases where culture and ideology have impact on negotiations because most of these factors influence negotiation indirectly, rather than directly. As such, the cultural or ideological factors have the risk of falling into consequence-oriented Interpretations. Nevertheless, the ideological or cultural factors are important because they are the foundations underlying the behavior of the negotiation parties. This perspective is reflected in recent studies of negotiation, where the importance of studying cultural and ideological factors are increasing day by day.

Table 2. Comparison of structural factors in China's negotiation with Taiwan and South Korea's negotiation with North Korea

\begin{tabular}{|c|c|c|}
\hline Classification & China & South Korea \\
\hline $\begin{array}{l}\text { Cultural } \\
\text { factor }\end{array}$ & $\begin{array}{l}\text { - Emphasis on cause } \\
\text { - Tributary Trade system } \\
\text { - Sinocentrism } \\
\text { - Emphasis on trust }\end{array}$ & $\begin{array}{l}\text { - Emphasis on practical benefit } \\
\text { - Negotiation for survival } \\
\text { - War experience }\end{array}$ \\
\hline $\begin{array}{l}\text { Ideological } \\
\text { factor }\end{array}$ & $\begin{array}{l}\text { - Nationalism } \\
\text { - Communism }\end{array}$ & $\begin{array}{l}\text { - Nationalism } \\
\text { - Democracy }\end{array}$ \\
\hline $\begin{array}{l}\text { Institutional } \\
\text { factor }\end{array}$ & $\begin{array}{l}\text { - EOrganization operation: regular } \\
\text { - Authority: integrated } \\
\text { - Organizational structure: fixed } \\
\text { - Nature: semi-official, semi-private }\end{array}$ & $\begin{array}{l}\text { - Organization operation: one-off } \\
\text { - Authority: dispersed } \\
\text { - Organizational structure: flexible } \\
\text { - Nature: official }\end{array}$ \\
\hline
\end{tabular}

Source: Shin $(2019,153)$

Plus). EUN (2013) well explained the concepts, theories, and methodologies for this approach in his research. I appreciate the help of an anonymous reviewer in clarifying the use of some expressions in the first version of this thesis. 
Based on the content of this article, of the Internal factors in the negotiations of China and South Korea, the structural factors are compared as follows by classifying them into cultural, ideological and institutional factors. First, culture has influenced the Cross-Strait and Inter-Korean negotiations as follows. One of the means to enhance negotiation power is to secure legitimacy. Especially, China traditionally has the culture of prioritizing legitimacy over practical benefits. Legitimacy can be secured, depending on the case, with a cause or with historical legitimacy. Once legitimacy is secured, this can be used to gain the upper hand in negotiations.

Traditional mindset of China can be peeked in 'Sinocentrism' and 'Tributary Trade System.' This perspective involves benefitting the neighbors with generosity and having the mercy of granting royal gifts to the envoys more than the tributes received. This proud confidence of China can be found in its concessions on trade issues toward Taiwan. ${ }^{14}$ The generous behavior of China shown in its negotiations with the same ethnic people reflects the pride of the sinocentric nationalism that they are 'One People.' China's generous negotiation behavior shown in the process and outcome of the ECFA negotiations also reflect the impact of this aspect working as a factor. In the process of the ECFA negotiations, China consistently shows the behavior of making concessions on economic issues as long as its political objective is achieved. ${ }^{15}$

Also, China has a culture that values trusted relationship in negotiations. To build such trusted relationship, China does not frequently change the personnel in charge of the negotiations. Actually in the ECFA negotiations, from the '1st Jinjiang Meeting' in June 2008 when the talks of preliminary negotiation nature began until the " 5 th Jinjiang Meeting" in June 2010 when the agreement was executed, the representatives of the "Association for Relations Across the

\footnotetext{
${ }^{14}$ Certainly, the tributary trade system cannot be considered an equivalent to the ECFA of the present. This comparison is also not the intention of the author. However, during the negotiation process of the ECFA, it is true that China yielded many concessions to Taiwan, and it was also true that China's concessions were preliminary steps for its political agenda of achieving unification with Taiwan by increasing Taiwan's economic dependence on China. Here, the historical context of China's decisions to concede economic issues in achieving political purposes is used to explain the example of the ECFA. Hence, in this case, the tributary trade system was not used as a comparative equivalent to the ECFA of the present.

${ }^{15}$ However, the precondition of this generous attitude of China is Taiwan's acceptance of the 1992 Consensus. China tends to maintain a relatively generous attitude during negotiations with Taiwan, as long as the 1992 Consensus is respected by Taiwan. The negotiations for the ECFA were an iconic case of such a dynamic. Likewise, the Sinocentrism or Tributary Trade System of previous Chinese dynasties were also based on the precondition of the surrounding countries' symbolic obeisance to Chinese emperors. Therefore, the characteristics of Entry Strategy and the Tributary Trade System can be considered similar.
} 
Taiwan Straits(ARATS)" and the "Straits Exchange Foundation(SEF)"16 have been maintained the same without any replacement, and the people in charge were not replaced afterwards even during the implementation phase and the following negotiations. In a culture where relationship is emphasized, more discussions and agreements are likely to be made in preliminary negotiations than in the main negotiation, which merely confirms the agreed matters. In case of the ECFA negotiations as well, while the preliminary negotiations took about two years from 2008 Ma Yingjeou Presidential election period to January 2010 when the result of Cross-Strait joint research was announced, the main negotiation was rapidly signed in only five months after going through three rounds of working-level negotiations and one provisional negotiation. As such, China is making full use of its traditional culture, which commonly penetrates the people on both sides of the strait, to enhance its negotiation power.

South Korea's traditional cultural factors in its negotiation include the emphasis on practical Interest, negotiation for survival and experience of war. A key character of South Korea's negotiation culture toward North Korea is that it emphasizes practical Interest. Unlike China, South Korea prioritizes visible economic exchange cooperation without setting any strong precondition. Of course, its negotiation with North Korea is a part of the process for achieving the ultimate goal of reunification. However, South Korea does not set the reunification precondition as hard as China, showing a practical behavior. ${ }^{17}$

Another cultural factor appearing in South Korea's GIC negotiations originates from the experience of war. The dynasty's experience of using negotiation as a

${ }^{16}$ China's ARATS handles the Cross-Strait affairs based on its rights duly authorized by the Taiwan Affairs Office of the State Council, and Taiwan's SEF created by the government handles the affairs based on its rights duly authorized by the Mainland Affairs Council, an instrument of the Executive Yuan. Both ARATS and SEF have been jointly operating a negotiation system called "Crossstrait Cross-association." Although the administrative rights to legislate and execute

Cross-Strait policy are exercised by the State Council and Taiwan Affairs Office(China) and by the Executive Yuan and Mainland Affairs Council(Taiwan), open Cross-Strait contacts, negotiations and communications were all managed by ARATS and SEF through "Cross-strait Cross-association." The representatives of ARATS and SEF are designated as the representatives of the Cross-Strait negotiations while the Head of the Taiwan Affairs Office of the State Council(China) and the Head of the Mainland Affairs Council of the Executive Yuan(Taiwan) are designated as the representatives of the Inter-government Cross-strait Growth Meeting. Based on this organizational structure created between each government, we can see that the leading institutionalized organizations of China and Taiwan are ARATS and SEF respectively.

${ }^{17}$ The "practical interest" mentioned here to describe the cultural factors in South Korea's negotiation is not limited to economic interest alone. Rather, it means that South Korea prefers solving the issues it is facing to meeting other prerequisites, such as the 1992 Consensus, which is an essential prerequisite of the cross-strait negotiations. South Korea's aid to North Korea can be interpreted from the same perspective. 
survival strategy has influenced South Korea's problem-solving type negotiation strategy, of which negotiation behavior emphasizes a peaceful solution through dialogues. Historically, the dynasties on the Korean Peninsular always had no choice but to respond sensitively to the International political situation. Hence, negotiations based on the information gathering and its analysis were directly connected to the survival of a dynasty. This is the destiny of small and weak nations bordering a huge dynasty. A negotiation for survival differs from that for management in terms of its intensity. The negotiation method used as a survival strategy by the dynasties on the Korean Peninsular in the past still works as a factor, continuing to be relevant to the present South Korea's diplomatic negotiation strategy, which even in military confrontation situations emphasizes a problem-solving through dialogue and negotiation, and if necessary, responds in collaboration with the International community.

An ideological factor also has an impact on negotiations. South Korea's ideological factor in its negotiation culture can be explained with a nationalism and democracy. Historically, South Korea's nationalism has provided an ideological basis for the idea that South and North Korea, as one people, should overcome the current state of a division and pursue a reunification led by the Korean people. The democratic political regime seeks to tackle problems through a peaceful negotiation, not a fighting. Of course still, the negotiation behavior tends to be swayed depending on the government and the characteristics of the political leader. Basically, however, South Korea's negotiation behavior is characterized by the fact that it aims for a problem-solving through a rational decision-making process of a democratic nation and intends to fully comply with the global standards in Inter-government negotiations.

Since it is actually impossible to change an ideology in the process of negotiation, if an ideological issue emerges, it becomes extremely difficult to derive a successful negotiation. Hence, in the case of Inter-Korean negotiations, strategically most of the agreements are made through closed-door negotiations and the open main negotiation simply confirms and endorses the agreements. Also, South Korea does not break a negotiation based on ideological debate.

On the contrary, in China's negotiations with Taiwan, the issue arising from the difference in ideology is marginal because the Cross-Strait negotiations can take place only when the 1992 Consensus are agreed as a precondition. In other words, the ideological factor impacting China's negotiation with Taiwan is subordinate to the prerequisite of "One China" and the acknowledgement of the Interpretation of the 1992 Consensus. Therefore, as long as Taiwan agrees to the 1992 Consensus, the issues coming from different ideologies are not significant in the process of China's negotiation with Taiwan. As such, in the course of the 
Cross-Strait ECFA negotiations which started upon the acceptance of the 1992 Consensus, there has been little negative impact caused by ideological factors such as national legitimacy, mutual appellation and reunification.

Lastly, there is an institutional factor impacting negotiations. Institutional factors had significant impact on both the ECFA and the GIC negotiations throughout the entire phases. China and Taiwan have operated all the procedures of the ECFA negotiations through the semi-official, semi-private organizations: the ARART and the SEF. In the course of unfolding the ECFA negotiations from the preliminary negotiations to follow-up negotiations, unlike the case of South Korea, the negotiations were carried out under a relatively regular, consistent and stable negotiation system. In case of South Korea's GIC negotiations, throughout all the phases, the responsible entities involved a wide range of organizations such as private businesses, summit-level, minister-level, Ministry of Unification or its affiliated organization, and civic groups. As the operation of the organizations was not centralized, responsible organizations for each agenda were scattered in fragments, and the structure of the organizations was so frequently changed that it was difficult to secure continuity in its management (Lee 2017, 405-413).

To sum up, the difference between the Cross-Strait and Inter-Korean negotiation system lies in the management of organization, authority, organizational structure, nature and structural aspect. The Cross-Strait negotiation system is institutionally operated on a regular basis, and the responsible organization, authority and management are consistent and uniform. The structure of organization is also fixed around the ARATS and the SEF, and the nature of negotiation is semi-official / semi-private or party-toparty. Lastly, the Cross-Strait negotiations institutionally assume the nature of bilateral negotiation between China and Taiwan. On the other hand, the InterKorean negotiation system has not been institutionally regularized, and its responsible organization, authority and management are not consistent. As for the organizational structure as well, even though there exists the Ministry of Unification, legally the representative of the negotiation can be changed depending on situation to the President, Unification Minister, or specially designated person. Hence, in substance, the responsible authority is dispersed and organizational structure is also flexible. 


\section{COMPARISION OF POLITICAL AND ECONOMIC FACTORS}

\section{COMPARISON OF POLITICAL FACTORS}

Major political factors affecting China's negotiations with Taiwan include the Interpretation of the 1992 Consensus, Taiwan's political/social factor and China's domestic issues, while South Korea's negotiations with North Korea are affected by such political factors as domestic political issues and characteristics of the political leaders. Below table compares the political factors of both nations' negotiations by classifying them into more detail based on the content of this article.

Table 3. Comparison of political factors in China's negotiation with Taiwan and South Korea's negotiation with North Korea

\begin{tabular}{|c|c|c|c|}
\hline \multicolumn{2}{|r|}{ China } & \multicolumn{2}{|r|}{ South Korea } \\
\hline Political factor & Description & Political factor & Description \\
\hline $\begin{array}{l}\text { - Formal } \\
\text { agreement on } \\
\text { the } 1992 \\
\text { Consensus }\end{array}$ & $\begin{array}{l}\text { - Premise for dialogue and } \\
\text { negotiation } \\
\text { - Entry strategy }\end{array}$ & $\begin{array}{l}\text { - Political } \\
\text { ideology } \\
\text { system }\end{array}$ & $\begin{array}{l}\text { - Inherent approach toward } \\
\text { North Korea } \\
\text { - Exit strategy }\end{array}$ \\
\hline $\begin{array}{l}\text { - China's Internal } \\
\text { issues }\end{array}$ & $\begin{array}{l}\text { - Need for continued } \\
\text { economic development } \\
\text { - Need to maintain the CPC } \\
\text { leadership system } \\
\text { - Need for social stability } \\
\text { - Entry strategy }\end{array}$ & $\begin{array}{l}\text { - Change in } \\
\text { North Korea } \\
\text { policy }\end{array}$ & $\begin{array}{l}\text { - North Korea policy changes } \\
\text { depending of the camp and } \\
\text { ruling party } \\
\text { - Exit strategy }\end{array}$ \\
\hline $\begin{array}{l}\text { - Taiwan's } \\
\text { Political · Social } \\
\text { factors }\end{array}$ & $\begin{array}{l}\text { - Ruling party's Interpretation } \\
\text { of the } 1992 \text { Consensus } \\
\text { - Confusion in national identity } \\
\text { - Engagement strategy, link } \\
\text { strategy }\end{array}$ & $\begin{array}{l}\text { - Leader's } \\
\text { characteristics }\end{array}$ & $\begin{array}{l}\text { - Big influence on the change in } \\
\text { negotiation behavior } \\
\text { - lack of stabilizer } \\
\text { - Significant Presidential authority } \\
\text { - Frequent change in institution } \\
\text { - Little binding force of the } \\
\text { agreement } \\
\text { - Engagement strategy, } \\
\text { link/parallel strategy }\end{array}$ \\
\hline
\end{tabular}

Source: Shin $(2019,156)$

The political factors influencing China's negotiations with Taiwan are characterized as follows. Activation or suspension of the Cross-Strait negotiations depends on how Taiwan Interprets the "One China Principle" and the "1992 Consensus" maintained by China. That is, the 1992 Consensus is the prerequisite of the Cross-Strait relations, and the Cross-Strait negotiations are 
subordinate to its Interpretation. As long as Taiwan acknowledges the 1992 Consensus, a dialogue with China is possible anytime.

Rather, the factors directly impacting the Cross-Strait negotiations originate from Taiwan's political/social issues. Like South Korea, Taiwan's controlling political party's characteristics has significant impact on the Cross-Strait relations. For example, all the agreements after 2008 when the Cross-Strait dialogue resumed were made during the KMT regime. The ECFA was also signed under the KMT's ruling. However, since the Democratic Progressive Party(DPP), who did not accept the 1992 Consensus, controlled the government, the ECFA follow-up negotiations have been suspended until now. Also, what the public opinion within Taiwan is like on reunification is another important factor.

Meanwhile, in case of South Korea's negotiation with North Korea, there is no absolute factor such as the ' 1992 Consensus.' Rather, South Korea excludes any politically sensitive matter and refrains from mentioning a political ideology system or the likes in order to talk North Korea into coming to the negotiation table. In other words, through an inherent approach, South Korea shows a flexible attitude toward such issues as political ideology system. On the matters related to a political ideology such as 'Self-Reliance Ideology', 'human rights issue' and 'establishment of national relations,' the South Korean government maintains an ambiguous attitude in the state of negotiation with North Korea by avoiding any firm remark. This is because the South Korean government believes that improving the Inter-Korean relations on exchange and cooperation front through inherent approach works more favorably to the development in the overall Inter-Korean relations.

Change in policy based on the change in regime is another characteristic political factor impacting South Korea's negotiations with North Korea. South Korea has a long-term reunification methodology based on the principles of autonomy, peace and democracy as well as a short-term policy toward North Korea, which changes every 5 years when a new government takes office. Also, depending on the ruling party, the understanding and attitude toward reunification method differs. Although they share the idea that a peaceful reunification should be the ultimate goal for both Koreas, generally a conservative regime takes a hard-line attitude while progressive regime takes a soft-line and engagement approach. The North Korea policy changing every 5 years and accordingly changing attitude toward North Korea have undermined the continuity and trust in Inter-Korean relations and works as a factor weakening South Korea's negotiation power against North Korea.

The impact of South Korean leader's characteristics on Inter-Korean relations is not insignificant. As mentioned above, South Korea's North Korea policy 
direction changes depending on the ruling party. As the leader is elected from the representatives of the ruling party, his/her characteristics is aligned with the characteristics of the ruling party. In particular, the intensity or level of the policy is significantly affected by the individual leader's characteristics. For instance, the 'July 4th Inter-Korean Joint Statement,' which marked an important turning point in the Inter-Korean relations, and afterwards the 'Inter-Korean Basic Agreement,' which laid the groundwork for establishing the Inter-Korean relations, were all signed under the conservative regime of Park Chunghee and Roh Taewoo government. Although the three rounds of the GIC crisis in 2008, 2013 and 2016 all occurred under the conservative regime, South Korea's response was different. In 2008 under the Lee Myungbak government, the GIC was not shut down. However, during the second and third crisis under the Park Geunhye government, it was all closed down. In the second crisis, the GIC came to be re-operated through negotiations. However, the closedown in 2016 still remains so as of now. That the Inter-Korean relations under conservative government differs depending on the leader also works as a factor impacting South Korea's negotiations with North Korea. ${ }^{18}$

Therefore, the political factors affecting South Korea's negotiation with North Korea generally arise from within South Korea, and most of them are caused by the absence of consensus and lack of consistent North Korea policy. As for China's Internal political factors affecting its negotiation with Taiwan, rather than such political factors as change in the power structure of the Communist Party of China(CPC) or characteristics of its leader, it is more desirable to find them in China's continued economic development, the gap between the rich and poor, minority ethnic group issue and Taiwan's political problems, etc. That is because continuously securing legitimacy for the CPC leadership system by resolving these Internal issues of China is more important to implementing China's consistent policy toward Taiwan,

\section{COMPARISON OF ECONOMIC FACTORS}

In China's negotiations with Taiwan and South Korea's negotiations with North Korea, China and South Korea are in the stance of providing dispensation. Accordingly, both nations employ engagement strategy. This dispensational attitude of China and South Korea is prominent in the negotiations on the

${ }^{18}$ The author believes North Korea provided the fundamental reason for suspension of the GIC project. The two Koreas went through various security-related disputes, represented by the nuclear issue and Cheonanham Incident, and the uncertainties of the North Korean situation have always threatened the GIC. The current global sanctions on North Korea due to the nuclear issue are also preventing the re-operation of the complex. 
economic front. As for the economic factors affecting China's negotiations with Taiwan, the economic situation in Taiwan, rather than China, has more impact. The economic factor affecting South Korea's negotiations with North Korea is the economic situation in South Korea. Taiwan's acceptance of the 1992 Consensus, a political factor, was the critical factor that started the full-fledged Cross-Strait negotiations.

However, a political factor alone is not sufficient to explain the fact that the agenda and nature of the Cross-Strait negotiations are set in the framework of economic trade negotiation, the ECFA. It can be said that economic factors such as Taiwan's economic situation have played a part. In other words, although the critical factor for China to start the negotiation with Taiwan is Taiwan's political factor, the ECFA negotiation was affected by the economic situation within Taiwan which has further aggravated since the 2008 global financial crisis.

The economic factor affecting South Korea's negotiations with North Korea is also not bigger than the influence of political factor. It is already known that the GIC project was pushed ahead politically as part of the engagement policy toward North Korea. However, just like the Cross-Strait negotiations, the fact that the nature of Inter-Korean economic cooperation negotiation was set as Inter-Korean joint venture project, the GIC, was greatly affected by the Internal and external economic factors in South and North Korea. The GIC project was made possible because it could lead to an economic cooperation where the exchange of comparative advantages of South Korea's accumulated capital and technology and North Korea's labor force and land could create a win-win outcome. Besides, the project could help SMEs in South Korea find a way out as their biggest burden was the labor cost. This was also one of the driving factors for the GIC negotiations to reach agreement smoothly.

Table 4. Comparison of economic factors in China's negotiations with Taiwan and South Korea's negotiations with North Korea

\begin{tabular}{|c|c|c|c|}
\hline \multicolumn{2}{|r|}{ China } & \multicolumn{2}{|r|}{ South Korea } \\
\hline Economic factor & ECFA & Economic factorr & GIC \\
\hline - Basic nature & $\begin{array}{l}\text { - Dispensational } \\
\text { - Concession in the items for } \\
\text { free trade } \\
\text { - Recognize as investment } \\
\text { within China } \\
\text { - Strong Internal negotiation } \\
\text { power in light of economic } \\
\text { situation }\end{array}$ & - Basic nature & $\begin{array}{l}\text { - Dispensational } \\
\text { - Provision of SOC, construction } \\
\text { \& technology } \\
\text { - Salary and land use fee, etc. } \\
\text { - Recognize as an investment to } \\
\text { outside } \\
\text { - Weak Internal negotiation power } \\
\text { in light of economic situation }\end{array}$ \\
\hline
\end{tabular}




\begin{tabular}{l|l|l|l}
\hline \multicolumn{2}{|c|}{ China } & \multicolumn{2}{c}{ South Korea } \\
\hline Economic factor & \multicolumn{1}{c|}{ ECFA } & Economic factorr & \multicolumn{1}{c}{ GIC } \\
\hline $\begin{array}{l}\text { China's } \\
\text { situation }\end{array}$ & $\begin{array}{l}\text { Confidence in economic } \\
\text { capacity } \\
\text { - Need for continued economic } \\
\text { development }\end{array}$ & $\begin{array}{l}\text { - South Korea's } \\
\text { economic } \\
\text { situation }\end{array}$ & $\begin{array}{l}\text { Confidence in economic } \\
\text { development } \\
\text { Need for continued economic } \\
\text { development } \\
\text { - Effect on the real economy }\end{array}$ \\
\hline $\begin{array}{l}\text { Taiwan's } \\
\text { situation }\end{array}$ & $\begin{array}{l}\text { Strong influence } \\
\text { - ECFA benefit distribution } \\
\text { issue } \\
\text { - Conflict between } \\
\text { generations, social classes }\end{array}$ & $\begin{array}{l}\text { - Internal } \\
\text { negotiation } \\
\text { power }\end{array}$ & $\begin{array}{l}\text { Negotiation power becomes } \\
\text { weak during economic downturn }\end{array}$ \\
\hline
\end{tabular}

Source: Shin $(2019,159)$

As afore-mentioned, the attitude of China's ECFA negotiations with Taiwan was dispensational. By simply looking at the qualitative and quantitative aspects of the items both countries opened to each other, we can see that China made substantial concessions to Taiwan. This is also the case with South Korea. In the course of the GIC negotiations, North Korea only provided the labor force and land while South Korea invested all the SOC businesses such as infrastructure construction and showed the manner of respecting North Korea's opinion for considerable parts in the salary and land use fee. Of course, in the background for China and South Korea to take dispensational stance to its respective counterparty lied the political purpose of integration through advancement in the relations, beyond the purpose of pursuing mutual economic benefits with the ECFA and the GIC project. However, this strategy was able to be realized because they had a confidence in their own economic capacity.

The economic factors in Taiwan and North Korea also work as factors affecting the negotiation. In Taiwan, a criticism is rising that the economic benefits generated from the ECFA are not being fairly distributed to the overall society. In particular, the youth suffering from the high unemployment rate are strongly dissatisfied. This economic situation within Taiwan works against the implementation of a follow-up ECFA negotiations. North Korea's economic factors have limited impact as compared to that of Taiwan. Since North Korea's trade with China accounts for most of its national trade, the effect of the GIC on North Korean economy is not so significant as compared to Taiwan's reliance on its trade with China.

Based on this result of comparison of the economic factors affecting China's negotiations with Taiwan and South Korea's negotiations with North Korea, 
following facts can be confirmed. First, China and South Korea are maintaining their dispensational stance toward Taiwan and North Korea respectively on economic negotiations. Second, the confidence of China and South Korea in their economic development work as a positive factor for their economic negotiations with Taiwan and North Korea because this leads them to show an embracing negotiation behavior. Third, despite the similarity in their economic factors affecting the negotiation, there is a difference in terms of the outcome in the implementation stage, which comes from the difference between China's recognition of Taiwan and South Korea's recognition of North Korea. Basically, China recognizes Taiwan as part of China. This recognition is the foundation to consistently maintain its economically dispensational policy toward Taiwan. Therefore, China's economic policy toward Taiwan does not involve the idea of providing aid to another nation, rather it is recognized as an investment within China. This is not the case with South Korea. Basically, South Korea recognizes North Korea as a counterpart to be reunified someday as the same ethic people of their own. However, since the armistice, North Korea has virtually formed its relationship with South Korea as an equal, nation-to-nation relation. Thus, South Korea's dispensational benefits given to North Korea are likely to be perceived as an aid to North Korea, as opposed to the investment within South Korea. $^{19}$

Due to these different perspectives, when the Cross-Strait or Inter-Korean relations turn sour or the economic situations of China and South Korea become unfavorable, the level of resistance within each nation against such dispensational economic policy are not the same. Based on the negotiation theory, China has a strong Internal negotiation power on its dispensational policy toward Taiwan while South Korea has a weak negotiation power regarding its dispensational policy toward North Korea. This factor can be one of the factors causing the difference between the outcome of China's negotiation with Taiwan and that of South Korea's negotiation with North Korea.

19 Also, the ECFA between China and Taiwan have other targets: strengthening China's economic influence in the region, including the economic connection among China, Taiwan, Hong Kong, Macao, and other Southeast Asian countries; and strengthening China's political influence in the region by increasing Taiwan's economic dependence on China. Therefore, from the perspective of China, closing the ECFA in favor of Taiwan was a kind of investment. In the case of the two Koreas, the GIC project was a combination of South Korea's capital and technologies and North Korea's lowcost workforce and land. However, as previous research on the project and the current status of the GIC suggest, the economic effects of the complex were insignificant. Since its launch, the project has been mainly influenced by political issues as opposed to economic issues. Therefore, the project is being considered a kind of economic aid to North Korea. 


\section{EXTERNAL FACTORS: COMPARISON OF THE US FACTOR}

Many scholars agree that the influence of the United States is so significant to the extent that the Cross-Strait and Inter-Korean relations are basically SinoUS and South-North-US relations respectively. Sino-US relations, along with the Interpretation of the 1992 Consensus, are the biggest key factors deciding the Cross-Strait relations. Historically, when the Sino-US relation was good, the Cross-Strait relation was also in thawing mood with negotiations actively taking place. On reverse, when the Sino-US relation aggravated, the CrossStrait relation turned sour as well and the negotiations were suspended. This pattern has appeared repeatedly. In case of Inter-Korean relations, due to the nuclear issue, the US can be involved more directly in the issues on the Korean Peninsular. Also, historically, the Inter-Korean relations have continuously repeated the pattern that South Korea's diplomatic activity scope expands when the Korea-US relation is good, resulting in active Inter-Korean negotiations, and vice versa.

Based on the general fact that the US influences the Cross-Strait and InterKorean relations, the US factor can be analyzed as an external factor affecting China's negotiations with Taiwan as follows. Since the US Intervened in the Taiwan Strait issue after the Korean War, until today it has been using Taiwan as a strategic card to play against China. The US factor's direct or indirect involvement is present in almost all issues related to China and Taiwan. From China's perspective, the US factor affecting Taiwan issue has two aspects. First, the presence of the US on the Taiwan Strait is weakening China's strategic effect of isolating Taiwan from the International community. Second, the US is using the Taiwan issue as a strategic card in its negotiations with China to weaken China's negotiation power against the US. In short, since the Sino-US relation was converted to the "strategic cooperation" relationship, the Interaction between Sino-US relation and Taiwan issue lies in the US attitude toward the "One China" as well as Sino-US trade dispute. However, the attempt of the US to use Taiwan as its strategic card in the negotiations with China is effective only when it does not infringe the key Interest of China such as Taiwan's independence issue.

The US factor in the course of the ECFA negotiations was limited. This was because the economic influence expansion strategy employed by China toward Taiwan at that time was successful for some part. China then was pursuing the ASEAN + 3 FTA and was proactively pushing ahead a FTA with South Korea which was constantly compared with Taiwan - increasing concerns in Taiwan of the isolation within the region. On top of that, the 2008 global economic crisis caused by the US rendered Taiwan's economic indicators in negative growth. 
To overcome this economic downturn, Taiwan herself became more active in driving the ECFA negotiations with China. In other words, the ECFA negotiation was the result of Taiwan's aggressive attitude combined with China's active response, and the impact of the US factor was rather limited.

Among the external factors affecting South Korea's negotiations with North Korea, also the US factor is the largest. While the Korean Peninsular was going through the process of liberation and national foundation, the US has deeply Intervened in the issues happening on the Peninsular. Especially, in the course of South Korea experiencing important changes including the Korean War, Cold War, industrialization and globalization, the US has firmly established itself as the biggest ally of South Korea and as the central anchor in the power structure within the region around the Korean Peninsular. Not just security issues like North Korean nuclear issue, but the Inter-Korean economic cooperation front is also absolutely subject to the US influence. For example, if we look at the process of the GIC negotiations from the perspective of Inter-Korean relations framework, the GIC is one of the projects carried out for the purpose of establishing a peace regime through Inter-Korean economic cooperation and exchanges. However, if we look at this more broadly from the global level, the GIC project is under the influence of the South Korea-North Korea-US triangle structure. This is because the North Korean issue as represented by the nuclear issue is giving the tension to the key Interests of the US.

In the process of the GIC negotiations, the diplomatic autonomy the South Korean government was able to take was possible only to the extent that it does not infringe the strategic Interests of the US. The US is seeing the North Korean nuclear issue as the key threat to its national security and is pressing North Korea by mobilizing all the diplomatic means required to resolve this. Here the pressure on the GIC is also included, and occasionally the US uses the vulnerable status of the GIC in terms of International law to press South Korea or uses the GIC as a negotiating card in its negotiation with South Korea to press South Korea. 
Table 5. Comparison of the US factor in China's ECFA negotiation and South Korea's GIC negotiation

\begin{tabular}{|c|c|c|c|}
\hline \multicolumn{2}{|r|}{ China's ECFA negotiation } & \multicolumn{2}{|c|}{ South Korea's GIC negotiation } \\
\hline US factor & $\begin{array}{l}\text { - Weak US influence } \\
\text { - Separated from the arms export } \\
\text { issue } \\
\text { - Unable to use as a card to press } \\
\text { China } \\
\text { - Weak influence regarding the } \\
\text { resumption of ECFA negotiation }\end{array}$ & US factor & $\begin{array}{l}\text { - Dispensational Strong US } \\
\text { influence } \\
\text { - Linked with North Korean nuclear } \\
\text { issue } \\
\text { - Used as a card to press South } \\
\text { Korea } \\
\text { - Strong influence regarding the } \\
\text { future re-operation of the GIC }\end{array}$ \\
\hline
\end{tabular}

Source: Shin $(2019,162)$

In the Cross-Strait relations, although the influence of the US on the Taiwan Strait is strongly demonstrated per se, as shown in the above China's ECFA negotiation case, at least in the economic negotiations between China and Taiwan the US factor is displayed with limitations. In case of South Korea, because the security issues such as North Korean nuclear issue on the Korean Peninsular are linked with economic issues, and due to the impact of the US strategy toward North Korea, the US exerts a very direct influence on the overall process of the negotiations for economic cooperation, such as the GIC negotiation.

Fundamentally, the GIC has an issue of violating the sanctions against North Korea imposed by the International community, involving the restriction on strategic materials transfer, workers' human rights and salary, country of origin mark and so forth. The US sometimes makes use of this issue of the GIC as a strategic card in its negotiations with South Korea. A good example is the case of the South Korea-US FTA negotiations where the US used this GIC issue in its negotiation strategy.

Both the Cross-Strait and Inter-Korean relations are bound to be strongly influenced by the US factor. Frankly speaking, if the US influence over Taiwan is removed, the Cross-Strait relations will take on a new dimension, very different from the current state, which will also be the case with the InterKorean relations. However, in terms of economic negotiations, the US influence on China and South Korea has substantial difference. This difference results from the difference in total national capacity between China and South Korea. Since this is already a given fact, there is no point of comparing. Rather, more noteworthy is the fact that the ECFA negotiations rapidly progressed owing to Taiwan's proactive manner, which was positively responded by China as well, 
rendering the US influence minimal on the ECFA negotiations and removing the Intervention by a third party. The removal of a third party Intervention made the ECFA negotiations assume a nature of bilateral negotiation and also expanded the scope of resolutions that could be achieved through mutual discussion.

Meanwhile, South Korea's GIC negotiation in its early stage when the InterKorean relations advanced took the structure of a bilateral negotiation. Later on, however, amid souring Inter-Korean relations, it became difficult for the principal parties - South and North Korea - to take the lead of the negotiations like the ECFA negotiation. In particular, the International community's sanctions against North Korea and the US Intervention on the Korean Peninsular, resulting from North Korea's nuclear development, changed the structure of the GIC negotiation to a multilateral negotiation where a third party is involved.

\section{CONCLUSION}

From 1992 to 2016, China and Taiwan conducted 47 formal meetings based on agreement document and signed 23 agreements. In fact, except for the talks of political nature arising from the change in Taiwan's political power structure, exchange cooperation is still continuing in all areas. In case of South Korea, Despite the quantitative fruits in signing agreements, in terms of actual delivery of the agreements including the 'Inter-Korean Basic Agreement,' they have lost their practical function. This quantitative and qualitative differences in negotiations result from the following distinct characteristics of the Cross-Strait and Inter-Korean relations.

South Korea's negotiation strategy toward North Korea basically takes pragmatic approach emphasizing practical Interests, based on the recognition of the reality that the nuclear issue and Inter-Korean issue became International issues. China's negotiation strategy toward Taiwan also assumes pragmatic strategy. The only difference between the two nations is the strategy related to reunification. However, even on this issue, if China and Taiwan reach an agreement on the 1992 Consensus, the stage is immediately set for resuming negotiation anytime. In other words, the influence of strategy on the different performance between Cross-Strait and Inter-Korean negotiations has been limited. Thus, in order to derive the implications from the Cross-Strait negotiations on the Inter-Korean negotiations, rather than studying the negotiation strategy per se, it is more important to analyze the factors affecting the negotiations. Five implications can be derived from the comparison of the 
negotiation factors.

First, it is important for South Korea to hold the negotiations on a regular basis by institutionalizing the organization responsible for the Inter-Korean talks. Not only that, it is also critical to explore ways to grant a legal status to the Inter-Korean agreements. The Cross-Strait agreement documents have the nature of treaty based on the International law. This means that the Cross-Strait agreements are effective per se. In case of the Inter-Korean Basic Agreement, however, the Constitutional Court Interpreted in 1997 that it does not have a legally binding force because it was not ratified by the National Assembly. In short, the institutional factor of the Cross-Strait negotiations gives two implications on South and North Korea. First is an institutionalization . regularization of the organization responsible for the negotiations and second is finding ways to grant a legal status on the Inter-Korean agreements.

Second, from strategic perspective, South Korea should adjust the critical point of its engagement strategy against North Korea to the level of the critical point of China's engagement strategy against Taiwan, which exists within the scope of not tolerating Taiwan's military provocation. In case of South Korea, the critical point of engagement strategy differs depending on the government. This situation only increases the uncertainty in the Inter-Korean relations. Therefore, South Korea should clearly define the scope of tolerance for the engagement strategy to minimize the uncertainty in the Inter-Korean relations.

Third, South Korea should minimize the changes in its North Korea policy arising from the change of the camp and ruling party. Above all, under the current presidential system with the president having a strong authority, a situation where the individual president's characteristics affects the North Korea policy should be avoided. A consistent and stable North Korea policy is required for advancing Inter-Korean relations through mutual trust.

Fourth, South Korea needs to abandon the perception that Inter-Korean economic cooperation is an aid to North Korea, and instead it should regard it as an investment. China consistently maintains its economically dispensational policy toward Taiwan because there is the underlying perception that China's economic cooperation with Taiwan is a domestic investment, not an aid. This perspective reduces the level of Internal backlash arising from changes in the economic situation within China. South Korea is also taking a considerably concessive stance on the economic cooperation with North Korea. This situation will face an Internal resistance when South Korea's economic situation worsens. In short, to reduce domestic disturbance and enhance the Internal negotiation power during economic downhill, the change in perception is needed recognizing that economic cooperation project with North Korea is not a beneficiary aid, but 
an investment for pursuing mutual benefits.

Last but not least, the US influence on the Inter-Korean economic negotiations needs to be curtailed so that the negotiations can be led in the framework of a bilateral negotiation. Although the GIC negotiation was carried out in a bilateral structure at the early stage when the Inter-Korean relations were progressing, afterwards amid worsening Inter-Korean relations it was converted to a multilateral negotiation structure, shrinking the scope of possible resolutions. In this context, the case of China's ECFA negotiations can be a good reference for future Inter-Korean economic cooperation negotiations. As the Cross-Strait ECFA negotiations progressed rapidly with Taiwan's proactive attitude, a room for the US factor to Intervene was blocked. In other words, by minimizing the indirect involvement of the US, the scope of the possible resolutions that can be reached through mutual discussion expanded. Applying this case to the InterKorean relations, if the Inter-Korean relations are in a cooperative mood, by drawing out a proactive attitude from North Korea at least on the economic cooperation front, the negotiations can be carried out in a bilateral negotiation structure.

The fundamental mechanisms of the cross-strait negotiations and InterKorean negotiations share many commonalities, but the actual mechanisms that precede the two types of negotiation are quite different. For example, Taiwan has not reached a domestic consensus regarding the cross-strait relation: should they choose unification with or independence from China? Which nation should take charge of the unification or independence process? The nonexistence of the consensus weakens the capacity of Taiwan for domestic negotiations and becomes a risk factor for the cross-strait negotiations. On the other hand, South Korea has reached a meaningful level of domestic consensus regarding unification. Therefore, the ever-present Inter-Korean issues over reunification do not significantly affect the agenda of Inter-Korean negotiations. Furthermore, the two Koreas can have Inter-Korean summits. The two Koreas acknowledge each other's governments as realistic entities and counterparts for negotiation. By the same token, the summits can be held because they acknowledge the representativeness of each other's governments. It is an established theory that the opinions of the heads of governments have an absolute influence on statelevel negotiations. Therefore, the Inter-Korean negotiations can set and reach agreement on higher-level agenda.

Both sides of the Cross-Strait and both Koreas exist as a real entity to each other respectively, as a counterparty for actual negotiation and as a partner for real partnership. While studying the Cross-Strait negotiations, it is only natural that the Inter-Korean negotiations come across to one's mind. From 
the aspect of managing the divided relations, studying the success factor for the Cross-Strait negotiations will be worthy of reference for advancing the InterKorean relations. As shown in the ECFA case, although China and Taiwan are closely working together from functional perspective, it falls short of leading to a political negotiation toward an actual integration. On the contrary, in case of South Korea, although there was an attempt of functional approach, it has been far from sufficient from the outcome perspective since 2016 as shown by the shutdown of the GIC. In particular, in the process of negotiations, economic agenda is repeatedly being subordinated to political agenda. In case of the CrossStrait relations, although there has been no retreat in cooperative exchanges, the advancement to political integration is difficult. In case of South Korea, the outcome of cooperative exchanges falls far short of that of the Cross-Strait; if activated, however, it can be expanded to include a situation of political negotiation toward an integration. This is because South and North Korea can hold a summit meeting and thus are more favorable in setting and reaching an agreement on broader scope of negotiation agenda. In this sense, the GIC project, which was the model economic cooperation success case in InterKorean exchanges, is not a mere economic cooperation project but a project that can serve as a trigger for coexistence and coprosperity as well as a peaceful reunification. Therefore, an in-depth study on the Internal/external negotiation factors appearing in this process should be carried out continuously.

\section{REFERENCES}

C. Fred Bergsten. 1992. "The Primacy of Economics.” Foreign Policy 87, 3-24. Cheongwadae Briefings Speech's \& Remarks. 2018. "Pyeongyang Joint Declaration of September 20182 - (2).” Accessed at https://english1. president.go.kr/BriefingSpeeches/Briefings/322 (July 10, 2019).

Herb Cohen. 2001. You Can Negotiate Anything. New York: Citadel Press.

Heungho Moon. 2010. "The Negotiation Systems of China and Taiwan and Their Operation Procedure-Focusing an ARATS and SEF." China Studies 48, 311-330.

I William Zartman. 1983. The 50\% Solutions. New Haven: Yale University Press, pp.7-9.

Jongho Shin. 2010. The Characteristics of Exchanges and Cooperation

between China and Taiwan and the Implications for Inter-Korean

Relations. Gyeonggi Research Institute.

Kenneth T. Young. 1986. Negotiation with Chinese Communists. New York: 
McGraw-Hill, Inc.

Kwangki Park, Jungran Park. 2008. "South Korea's Policies towards North Korea and Reunification in the Past 6o Years Retrospect and Prospect." The Journal of Political Science \& Communication 11(1), 13.

Kyutae Lee. 2017. "A Study on Mechanism of Negotiation and Communication between China and Taiwan : Focusing on Its Implications for SouthNorth Korean Relations.” Ph. D. dissertation. North Korean Studies University.

Lin Wencheng. 2010. Theory and Practice of the CCP Negotiations: Concurrently Discussing the Cross-Strait Negotiations between the Taiwan Strait. Kaohsiung: Liwen Cultural Enterprise.

Max H. Bazerman, Margaret Neale. 1994. Negotiation Rationally. New York: Free Press.

Moonsoo Yang 2013. “A National Strategy to Restore Peace on the Korean Peninsula: A Case of Kaesong Industrial Complex.” National Strategy 19(2), 57-58.

Robert D. Putnam. 1988. "Diplomacy and Domestic Politics: the logic of twolevel games.” International Organization 42(2).

Ryoun Heo. 2011. "Achievements and Implications of Gae-Seong Development Project.” Journal of the Korean Geographical Society 46(4), 518.

Wonwoo Shin. 2019. "A comparative study on two negotiations between china with Taiwan and South Korea with North Korea : focusing on ECFA and Gaesong industrial complex.” Ph. D. dissertation, Hanyang University. William Ury. 2007. The Power of a Positive No. New York: Bantam.

Yougsoo Eun. 2013. "Psychological and Cognitive Approaches in IR." Korean Journal of International Relations 53(4), 101-105.

김연철. 2018. 『70년의 대화: 새로 읽는 남북 관계사』. 서울: 창비, 200-201.

린원청 저, 강병환 역. 2017. 『중국을 다룬다: 대중국 협상과 전략』. 고양: 学古房.

문흥호. 2007. 『대만문제와 양안관계』. 서울: 폴리테이아, 169.

이달곤. 2005.『협상론. 파주: 법문사』, 160 .

中華人民共和國中央人民政府。2010。“海峡两岸经济合作框架协议首次专家工行” (January 26). Accessed at http://www.gov.cn/jrzg/2010-01/26/ content_1519960.htm (July 10, 2019).

郑立中表示两岸协商ECFA会考虑台湾市场承受能力.” (December 22). Accessed at http://www.arats.com.cn/duihua/200912/t20091230_1205788.htm (July 10, 2019).

大公网. 2016. “海协会官员:无“九二共识, ECFA难再续谈.”(May 16) Accessed at www.sohu.com/a/75731562_162548 (July 10, 2019).

[Received Sep 30, 2019; Revised Oct 18, 2019; Accepted Dec 5, 2019] 